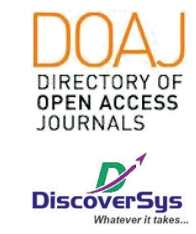

Published by DiscoverSys

\section{Hubungan antara Lingkar Lengan Atas (LILA) dan konsumsi tablet besi selama kehamilan terhadap berat badan lahir bayi di wilayah kerja Puskesmas Uabau, Kabupaten Malaka tahun 2019}

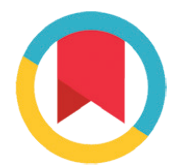

CrossMark

\author{
Ni Putu Inna Ariani, ${ }^{1 *}$ Sicilia Eha, ${ }^{2}$ Debora Shinta Liana ${ }^{3}$
}

\section{ABSTRACT}

Background: Birth weight is the baby's first weight obtained in less than 1 hour after birth. Maternal factors such as maternal nutrition before and during pregnancy can affect the birth weight of the baby, for example, deficiency of macro substances with one of the measurements in the form of the upper arm circumference (LILA) of pregnant women and micro iron, especially iron. This study aims to analyze the relationship between LILA and consumption of iron tablets during pregnancy and birth weight of babies in the working area of Uabau Public Health Services, Malacca Regency, in 2019.

Methods: This study used a cross-sectional approach to the medical records of 127 mothers who gave birth in the Uabau Public Health Services, Malacca Regency, in 2019, using the total sampling technique. The variables assessed in this study were LILA, consumption of iron tablets, and birth weight of the baby. Data were analyzed using SPSS version 17 for Windows.

Results: The results showed that the mean birth weight of infants was 2,967.72 \pm 377.83 grams, followed by LILA of $23.65 \pm 2.45 \mathrm{~cm}$, and consuming about 90 (10-160) tablets. The Spearman's correlation test shows that there is no significant correlation between maternal LILA ( $r=$ $0.103 ; p=0.247)$ and the amount of iron tablet consumption ( $r=0.065$; $p=0.471$ ) pregnant women to the weight of newborns in the working area of the Uabau Public Health Services, Malacca Regency in 2019.

Conclusion: Maternal LILA and the amount of iron tablet consumption during pregnancy do not show a significant relationship with the birth weight of babies in the work area of Uabau Public Health Services, Malacca Regency, in 2019.
Keywords: Baby Birth Weight, LILA, Pregnant Women, Iron Tablets

Cite This Article: Ariani, N.P.I., Eha, S., Liana, D.S. 2020. Hubungan antara Lingkar Lengan Atas (LILA) dan konsumsi tablet besi selama kehamilan terhadap berat badan lahir bayi di wilayah kerja Puskesmas Uabau, Kabupaten Malaka tahun 2019. Intisari Sains Medis 11(2): 702-705. D0I: 10.15562/ism.v11i2.657

\section{ABSTRAK}

Latar Belakang: Berat badan lahir adalah berat pertama bayi yang diperoleh dalam waktu kurang dari 1 jam pertama setelah lahir. Faktor maternal seperti gizi ibu sebelum dan saat hamil dapat mempengaruhi berat lahir bayi, misalnya defisiensi zat makro dengan salah satu pengukuran berupa Lingkar Lengan Atas (LILA) ibu hamil maupun zat mikro terutama zat besi. Penelitian ini bertujuan untuk menganalisis hubungan antara LILA dan konsumsi tablet besi selama kehamilan dengan berat badan lahir bayi di wilayah kerja Puskesmas Uabau, Kabupaten Malaka Tahun 2019.

Metode: Penelitian ini menggunakan pendekatan potong lintang terhadap rekam medis 127 ibu yang melahirkan di wilayah kerja Puskesmas Uabau, Kabupaten Malaka, pada tahun 2019 menggunakan teknik Total Sampling. Variabel yang dinilai pada penenlitian ini berupa
LILA, konsumsi tablet besi, dan berat badan lahir bayi lahir. Data dianalisis dengan SPSS versi 17 untuk Windows.

Hasil: Hasil penelitian menunjukkan bahwa rata-rata berat badan bayi lahir adalah 2.967,72 $\pm 377,83$ gram, diikuti dengan LILA sebesar $23,65 \pm 2,45 \mathrm{~cm}$, dan mengonsumsi sekitar 90 (10-160) tablet. Uji korelasi spearman's menunjukkan bahwa tidak terdapat korelasi yang bermakna antara LILA ibu $(r=0,103 ; p=0,247)$ maupun jumlah konsumsi tablet besi $(r=0,065 ; p=0,471)$ ibu hamil terhadap berat badan bayi baru lahir di wilayah kerja Puskesmas Uabau, Kabupaten Malaka Tahun 2019. Kesimpulan: LILA ibu dan jumlah konsumsi tablet besi selama kehamilan tidak menunjukkan adanya hubungan yang bermakna terhadap berat badan lahir bayi di wilayah kerja Puskesmas Uabau Kabupaten Malaka Tahun 2019.
Kata Kunci: Berat Badan Lahir Bayi, LILA, Ibu Hamil, Tablet Besi

Cite Pasal Ini: Ariani, N.P.I., Eha, S., Liana, D.S. 2020. Hubungan antara Lingkar Lengan Atas (LILA) dan konsumsi tablet besi selama kehamilan terhadap berat badan lahir bayi di wilayah kerja Puskesmas Uabau, Kabupaten Malaka tahun 2019. Intisari Sains Medis 11(2): 702-705. D0I: 10.15562/ism.v11i2.657 


\section{PENDAHULUAN}

Faktor maternal seperti gizi ibu sebelum dan saat hamil dapat mempengaruhi berat lahir bayi, misalnya defisiensi zat makro karena kekurangan energi kronis (karbohidrat, protein, dan lemak) maupun zat mikro terutama vitamin A, vitamin $\mathrm{D}$, asam folat, zat besi, seng, kalsium, dan iodium. ${ }^{1}$ Pada wanita usia subur yang berkelanjutan (remaja sampai masa kehamilan), mengakibatkan terjadinya kekurangan energi kronik (KEK) pada masa kehamilan, yang diawali dengan kejadian resiko KEK yang ditandai dengan rendahnya cadangan energi dalam jangka waktu cukup lama yang diukur dengan lingkar lengan atas (LILA)., ${ }^{2,3}$ Ibu hamil sebaiknya memiliki lingkar lengan atas lebih dari $23,5 \mathrm{~cm}$ pada trimester pertama kehamilan.,

Berdasarkan Riskesdas 2013 menunjukan prevalensi resiko KEK pada ibu hamil (15-49 tahun) sebesar 24,2\%, khususnya prevalensi tertinggi ditemukan pada usia remaja (15-19 tahun) sebesar $38,5 \%$ dibandingkan kelompok umur ibu hamil (20-24 tahun) sebesar 30,1\%. ${ }^{4}$ Di Provinsi Nusa Tenggara Timur (NTT), persentase ibu hamil dengan angka kecukupan energi (AKE) $<70 \%$ adalah 59,8\%, dan persentase ibu hamil angka kecukupan protein (AKP) $<80 \%$ adalah $61,4 \%{ }^{4,5}$ Untuk angka kecukupan protein (AKP) ibu hamil $<80 \%$ Provinsi NTT menduduki posisi ke 5 di Indonesia. ${ }^{4}$ Di Kabupaten Malaka pada Tahun 2017 didapatkan prevalensi ibu hamil KEK sebesar 19,4\%, khususnya di Puskesmas Uabau prevalensinya sebesar $23,1 \%{ }^{5}$

Faktor maternal berupa gizi ibu pada saat hamil yang mempengaruhi berat badan lahir bayi salah satunya yaitu defisiensi zat mikro berupa zat besi. ${ }^{6}$ Secara nasional, cakupan ibu hamil yang mendapat tablet besi minimal 90 tablet selama masa kehamilannya belum mencapai target, yaitu sebesar $80,4 \%$ dari target $85 \%{ }^{4}$ Di Kabupaten Malaka target yang dicapai pada Tahun 2017 adalah 95,7\%, khususnya di Puskesmas Uabau pada Tahun 2017 pencapaiannya 100\%. ${ }^{5}$ Masih adanya ibu hamil KEK di wilayah kerja Puskesmas Uabau, dan telah tercapainya target pemberian tablet besi pada Tahun 2017.

Beberapa penelitian menyebutkan bahwa ibu hamil KEK dan konsumsi tablet besi dapat mempengaruhi berat badan lahir bayi, akan tetapi beberapa penelitian terdahulu menunjukkan hasil yang berbeda. Berkaitan dengan latar belakang di atas, penelitian ini bertujuan untuk mengidentifikasi hubungan LILA ibu maupun konsumsi tablet besi selama kehamilan dengan berat badan lahir bayi di wilayah kerja Puskesmas Uabau Kabupaten Malaka Tahun 2019.

\section{METODE}

Penelitian ini menggunakan sumber data sekunder berupa buku KIA/rekam medis dan dikonfirmasi dengan wawancara 2 arah terhadap 127 responden dengan pendekatan potong lintang yang dipilih menggunakan teknik Total Sampling di wilayah kerja Puskesmas Uabau selama periode Juli 2018Juni 2019. Variabel status gizi ibu yang dinilai pada penelitian ini berupa Lingkar Lengan Atas (LILA) $(\mathrm{cm})$ dan jumlah konsumsi tablet besi pada masa kehamilan dimana parameter yang dinilai adalah berat badan bayi lahir (gram).

Adapun kriteria inklusi yang dipergunakan pada penelitian ini berupa berupa kesediaan responden sebagai subjek penelitian yang diperoleh dari persetujuan pernyataan tertulis atau informed consent dan bayi yang lahir berada pada usia kehamilan aterm (37-42 minggu). Sedangkan kriteria eksklusi pada penelitian ini berupa bayi yang lahir dengan status gemeli atau, bayi dengan kelainan kongenital, ibu dan bayi yang tidak memiliki buku KIA, serta ibu dan bayi yang catatan buku KIA tidak lengkap.

Tahap analisa dalam penelitian ini menggunakan analisi univariat dan analisis bivariat. Analisis univariat bertujuan untuk menganalisis karakteristik variabel. Analisis bivariat dilakukan untuk mengetahui hubungan antara dua variabel yakni variabel bebas dengan variabel terikat. Data yang sudah diperoleh akan dianalisis dengan piranti lunak SPSS versi 17 untuk Windows.

\section{HASIL}

Hasil penelitian menunjukkan bahwa rata-rata berat badan bayi saat lahir adalah $2.967,72 \pm 377,83$ gram, dengan berat lahir terendah 2.000 gram dan terberat 4.000 gram, dimana didapatkan median berat lahir bayi yaitu 2.990 gram (Tabel 1). Lingkar Lengan Atas (LILA) ibu saat hamil rata-rata 23,65 $\pm 2,45 \mathrm{~cm}$, dimana memiliki rentangan terlebar $34,5 \mathrm{~cm}$ dan terpendek $18,5 \mathrm{~cm}$, serta diperoleh nilai median LILA ibu saat hamil yaitu $23,5 \mathrm{~cm}$. Rata-rata konsumsi tablet besi ibu saat hamil yautu 86 tablet dengan konsumsi terendah yaitu 10 tablet dan konsumsi terbanyak 160 tablet, serta didapatkan nilai median konsumsi tablet besi ibu saat hamil yaitu 90 tablet (Tabel 1).

Berdasarkan hasil uji bivariat didapatkan bahwa analisis korelasi Spearman menunjukkan bahwa LILA ibu $(r=0,103 ; p=0,247)$ dan konsumsi tablet besi $(r=0,065 ; p=0,471)$ saat hamil tidak memiliki hubungan yang bermakna dengan berat badan lahir bayi di wilayah kerja Puskesmas Uabau Tahun 2019 (Tabel 2). 
Tabel 1 Karakteristik dasar responden penelitian

\begin{tabular}{lccc}
\hline Variabel & N & Rerata \pm SB & Median (min - max) \\
\hline Berat bayi lahir (Gram) & 127 & $2.967,72 \pm 377,83$ & $2.990(2.000-4.000)$ \\
LILA $(\mathrm{cm})$ & 127 & $23,65 \pm 2,45$ & $23,5(18,5-34,5)$ \\
Konsumsi tablet besi (Tablet) & 127 & $86,22 \pm 30,63$ & $90(10-160)$ \\
\hline
\end{tabular}

Tabel 2 Hasil uji korelasi Spearman terhadap berat bayi lahir

\begin{tabular}{lcc}
\hline & \multicolumn{2}{c}{ Berat Bayi Lahir } \\
\cline { 2 - 3 } Variabel & $\mathbf{r}$ & $\mathbf{p}$ \\
\hline Lingkar lengan ibu saat hamil & 0,103 & 0,247 \\
Konsumsi tablet besi ibu saat hamil & 0,065 & 0,471 \\
\hline
\end{tabular}

\section{PEMBAHASAN}

Hasil penelitian ini menjelaskan bahwa lingkar lengan atas ibu saat hamil tidak ada hubungannya dengan berat badan lahir bayi. Hal ini tidak sejalan dengan hasil penelitian Retni et al., yang menyatakan terdapat hubungan $(\mathrm{p}=0,010)$, dimana $\mathrm{ibu}$ KEK beresiko 16 kali melahirkan bayi berat badan lahir rendah $(\mathrm{OR}=16,31){ }^{7}$ Namun hasil penelitian ini sejalan dengan penelitian Happinasari $\mathrm{O}$ et al, Irmayanti, dan Andarbeni DP yang menyatakan tidak ada hubungan lingkar lengan atas ibu saat hamil dengan berat badan lahir bayi. ${ }^{8-10}$

Hasil observasi LILA yang ditemukan pada penelitian Irmayanti menunjukkan bahwa distribusi frekuensi status gizi ibu bersalin pada yang beresiko sebanyak $31,1 \%$ responden, sedangkan yang tidak beresiko berjumlah $68,9 \%$ responden. Hal tersebut menunjukkan bahwa sebagian besar ibu bersalin dalam kondisi gizi yang baik dan terbebas dari risiko KEK. Namun hasil ini tidak menunjukkan kondisi ibu bersalin secara keseluruhan karena terbatasnya jumlah sampel yang diteliti. ${ }^{9}$

Hal tersebut mungkin terjadi karena pengukuran LILA berguna untuk skrining malnutrisi protein. Pada saat protein menurun yang ditandai dengan LILA $<23,5 \mathrm{~cm}$ tidak menutup kemungkinan cadangan zat-zat gizi lainnya masih terpenuhi dengan baik seperti lemak, karbohidrat, mineral, zat besi dan sebagainya, sehingga masih memungkinkan ibu melahirkan dengan berat lahir normal. ${ }^{11}$ Menurut Assefa $\mathrm{N}$ et al., meskipun LILA dapat dijadikan salah satu faktor, tetapi ibu yang diawal kehamilan memiliki LILA maupun IMT yang normal tetapi tidak diikuti dengan pertambahan berat badan yang seharusnya, maka ibu tersebut juga berisiko melahirkan bayi BBLR. ${ }^{12}$ Selain itu kekurangan energi kronis maupun akut memiliki hubungan dan pengaruh dengan berat badan lahir bayi, namun kekurangan energi akut memiliki efek yang lebih nyata dibandingkan dengan kekurangan energi kronis. ${ }^{12}$
Hasil penelitian ini menyatakan tidak ada hubungan konsumsi tablet besi ibu saat hamil dengan berat badan lahir bayi. Hasil ini tidak sejalan dengan penelitian Retni et al., yaitu terdapat hubungan antara asupan zat besi dengan berat badan lahir rendah dengan pengaruh 4 kali lebih besar beresiko melahirkan bayi berat badan lahir rendah maupun penelitian Fikawati $S$ et al., yang menyebutkan terdapat hubungan bermakna.,13 Akan tetapi hasil penelitian ini tidak sejalan dengan hasil penelitian Ernawati F et al., yang menyebutkan tidak ada hubungan mendapat tablet besi dengan berat badan lahir bayi. ${ }^{14}$

Sebagian besar kejadian anemia pada ibu hamil disebabkan oleh defisiensi zat besi, mekanisme anemia dapat dijelaskan dengan beberapa keadaan yaitu kurangnya zat besi dapat mengganggu sistem imun sehingga rawan terhadap infeksi, meningkatkan produksi hormin stress norephinephrine dan kortisol, dan $\mathrm{Hb}$ yang rendah menyebabkan fetal hypoxia yang kemudian merangsang tubuh memproduksi hormone corticotrophine sehingga menghambat pertumbuhan janin. ${ }^{15}$ Penyebab lainnya kemungkinan kadar hemoglobin ibu masih berada pada batas normal. ${ }^{2,15}$ Namun pemeriksaan hemoglobin tidak dilakukan sehingga hal tersebut merupakan kekurangan dari penelitian ini.

Berat badan lahir dipengaruhi oleh 2 faktor, yaitu faktor internal dan eksternal ibu hamil. Faktor internal tersebut antara lain usia ibu, paritas, jangka waktu hamil, jarak kehamilan, status gizi, penyakit selama kehamilan, dan faktor genetik. Faktor eksternal seperti kebiasaan hidup ibu hamil, karakteristik asuhan antenatal, dan keadaan sosial ekonomi keluarga. ${ }^{16,17}$ Faktor-faktor lain yang mempengaruhi berat badan lahir yang belum dapat disingkirkan sebagai faktor perancu seperti keadaan sosial ekonomi, tekanan psikologis dan faktor-faktor lainnya. ${ }^{16,17}$

\section{SIMPULAN}

Pada penelitian ini tidak ditemukan hubungan lingkar lengan atas ibu, konsumsi tablet besi selama kehamilan dengan berat badan lahir bayi di wilayah kerja Puskesmas Uabau Kabupaten Malaka Tahun 2019. Perlu dilakukan penelitian selanjutnya dengan memasukkan faktor-faktor lainnya yang mempengaruhi berat badan lahir bayi sebagai variable penelitian, sehingga mendapatkan data yang lebih sempurna.

\section{KONFLIK KEPENTINGAN}

Tidak terdapat konflik kepentingan dalam pembuatan laporan hasil penelitian. 


\section{PERSETUJUAN ETIK}

Penelitian ini telah memperoleh persetujuan dari komisi etik sebelum dijalankan.

\section{PENDANAAN}

Penulis bertanggung jawab terhadap pendanaan penelitian ini tanpa melibatkan pihak sponsor.

\section{KONTRIBUSI PENULIS}

Seluruh penulis berkontribusi dalam pembuatan laporan hasil penelitian baik dari persiapan kerangka konsep, pengambilan data, analisis data penelitian, hingga laporan penelitian dalam bentuk publikasi ilmiah.

\section{DAFTAR PUSTAKA}

1. Radebe BZ, Brady P, Siziya S, Todd H. Maternal risk factors for childhood malnutrition in the Mazowe District of Zimbabwe. Cent Afr J Med. 1996;42(8):240-244.

2. Hamel C, Enne J, Omer K, Ayara N, Yarima Y, Cockcroft A, et al. Childhood Malnutrition is Associated with Maternal Care During Pregnancy and Childbirth: A Cross-Sectional Study in Bauchi and Cross River States, Nigeria. J Public Health Res. 2015;4(1):408.

3. Ricalde AE, Velásquez-Meléndez G, Tanaka AC, de Siqueira AA. Mid-upper arm circumference in pregnant women and its relation to birth weight. Rev Saude Publica. 1998;32(2):112-117.

4. Kementerian Kesehatan Republik Indonesia. Data dan Informasi Profil Kesehatan Indonesia 2016. Jakarta: 2016:120.

5. Dinas Kesehatan Kabupaten Malaka. Profil Kesehatan Kabupaten Malaka Tahun 2017, Betun. 2017:35.

6. Bonakdar SA, Dorosty Motlagh AR, Bagherniya $M$, Ranjbar G, Daryabeygi-Khotbehsara R, Mohajeri SAR, et al. Pre-pregnancy Body Mass Index and Maternal Nutrition in Relation to Infant Birth Size. Clin Nutr Res. 2019;8(2):129-137.
7. Retni, Margawati A, Widjanarko B. Pengaruh Status Gizi \& Asupan Gizi Ibu terhadap Berat Bayi Lahir Rendah pada Kehamilan Usia Remaja. Jurnal Gizi Indonesia. 2016;5(1):4-19.

8. Happinasari O, Suryandari AE. Pengaruh Kadar $\mathrm{Hb}$ dan Lingkar Lengan Atas (LILA) pada Ibu Hamil Trimester III terhadap Berat Lahir Bayi di Puskesmas Wilayah Kabupaten Banyumas. Jurnal Ilmiah Kebidanan. 2015;6(1):116-122.

9. Irmayanti. Hubungan Status Gizi Ibu Berdasarkan Ukuran LILA dengan Bayi Berat Lahir di BLUD Rumah Sakit Kabupaten Konawe Tahun 2017. Jurnal Ilmiah Kesehatan Diagnosis. 2018;12(2):228-231.

10. Andarbeni DP. Hubungan Lingkar Lengan Atas (LILA), Kadar Hemoglobin $(\mathrm{Hb})$, dan Frekuensi Antenatal Care (ANC) dengan Berat Bayi Lahir (BBL) di Rumah Sakit PKU Muhammadiyah Yogyakarta. Surakarta. 2012.1.

11. Benítez Brito N, Suárez Llanos JP, Fuentes Ferrer M, Garcia JGO, Brito ID, Castro FPG, et al. Relationship between Mid-Upper Arm Circumference and Body Mass Index in Inpatients. PLoS One. 2016;11(8):e0160480.

12. Assefa N, Berhane Y, Worku A. Wealth status, mid upper arm circumference (MUAC) and antenatal care (ANC) are determinants for low birth weight in Kersa, Ethiopia. PLoS One. 2012;7(6):e39957.

13. Fikawati S, Wahyuni D, Syafiq A. Status Gizi Ibu Hamil dan Berat Lahir Bayi pada Kelompok Vegetarian. Jurnal Makara Kesehatan. 2012:16(1):29-35.

14. Ernawati F, Kartono D, Puspitasari DS. Hubungan Antenatal Care dengan Berat Badan Lahir Bayi di Indonesia (Analisis Lanjut Data Riskesdas 2010). Jurnal Gizi Indonesia. 2011;34(1):23-31.

15. Abu-Ouf NM, Jan MM. The impact of maternal iron deficiency and iron deficiency anemia on child's health. Saudi Med J. 2015;36(2):146-149.

16. Karima K, Achadi EL. Status Gizi dan Berat Badan Lahir Bayi. Jurnal Kesehatan Masyarakat Nasional, 2012;7(3):111-119.

17. Tyagi S, Toteja GS, Bhatia N. Maternal Nutritional Status and Its Relation with Birth Weight. Journal of Health Sciences \& Research. 2017;7(8):422-433.

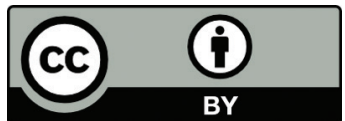

This work is licensed under a Creative Commons Attribution 